\title{
The Effect of Ambient Temperature on Some Biochemical Profiles of Black Bengal Goats (Capra aegagrushircus) In Two Different Agro-Climatic Zones in West Bengal, India
}

\author{
Mihir Bhatta ${ }^{1}$, DebasishDas ${ }^{1}$, ProbalRanjan Ghosh ${ }^{2}$ \\ ${ }^{I}$ (Department of Environmental Science, University of Kalyani, Kalyani-741235, West Bengal, India) \\ ${ }^{2}$ (Department of Veterinary Physiology, West Bengal University of Animal \& Fishery Sciences. 37 Khudiram \\ Bose Sarani, Kolkata-700037. West Bengal, India.)
}

\begin{abstract}
Being a multipurpose animal goat can produce meat, milk and hide. India has a good number of Black Bengal goat populations, which has an important role in the lives of local goat rearers. The goal of the present study is to find out the effects of changing seasons on some biochemical parameters ofBlack Bengal goat (Capra aegagrushircus) in two different agro-climatic zones in India. The highest mean value of temperature $\left(42.6 \pm 1.5^{\circ} \mathrm{C}\right)$ has been reported during the month of April or May in the season of pre-monsoon in Purulia. However, the lowest value of temperature $\left(8.6 \pm 0.9^{\circ} \mathrm{C}\right)$ has been reported during the month of December or January in the season of post-monsoon again in Purulia. The parameter studied here are blood $\mathrm{pH}$, blood glucose level, concentration of Hb, RBC count, PCV, MCV, MCH and MCHC. Data has analyzed for the effect of seasonal variation among in both the regions and the current findings implies that not only seasonal variation but the regional variation also influence the major biochemical responses of goats.
\end{abstract}

Keywords: Goats, pre-monsoon, post-monsoon, Purulia, Nadia

\section{Introduction:}

Goat being a multipurpose animal which can produce meat, milk and hide is an important choice to the small and marginal farmers of India, especially West Bengal. Goat production in India makes a major contribution to the agrarian economy (1). Here we choose among the several goat breeds of India, black Bengal goats (Capra aegagrushircus) (2) majorly distributed throughout Eastern India and best in terms of meat and leather quality (1). Although goats are known to be adapted to harsh environments but their productivity is affected adversely by extreme climatic conditions. Lowering of food intake and decrease in meat as well as milk production are commonly observed in heat stressed goat (3). In the present scenario of global climate changes, the physiological response of goat to elevated temperature is a major focus to maintain the goat rearing a sustainable venture (3).

Several biochemical markers are identified to assess the health status of goat exposed to stress (4). The monitoring of blood constituents in a regular interval can predict the unnatural physiological condition and to formulate strategies which may prevent massive loss in goat husbandry due to pathogens or climatic factors.

The present study was carried out to study seasonal as well as zone wise variation in different physiobiochemical parameters of Black Bengal goat in two agro-climatic regions of India viz. Purulia, fall under Eastern Plateau and Hills region(5)and Nadia, fall under Lower Gangetic Plains region(6) of India with special reference to changes in ambient temperature.

\section{Materials And Methods:}

2.1 Animals: The animals used in this study were clinically healthy Black Bengal bucks of $2-3$ years of age and has an average body weight of about $15 \mathrm{Kg}$ showing no parasitic infestation. The animals were taken from the local rearers of Lakshmipur village $\left(23^{\circ} 21^{\prime} \mathrm{N}, 8^{\circ} 5^{\prime} \mathrm{E}\right)$ of Purulia district and in Mohanpur farm $\left(22^{\circ} 56^{\prime} \mathrm{N}, 88^{\circ} 31^{\prime} \mathrm{E}\right)$ of Nadia district, both from the state of West Bengal, there are no feed restriction to the goats. Animals were maintained in its ambient condition for four weeks prior to blood sampling.

2.2 Study areas: Planning Commission of India, in 2006has demarcated the geographical area of India into 15 agro-climatic regions. The present studies have been carried out into two agro-climatic zones of India. These are as follows:

2.2.1. Purulia, fall under Eastern Plateau and Hills region of India (5). This agro-climatic zone is Located at the southern tip of Bihar. Thirty per cent of the area is classified as forests and only about a quarter of the area is cultivated. It receives about $1,200 \mathrm{~mm}$ of rainfall annually. The climate is moist sub-humid to sub-humid and the soil is red loamy, red and yellow.Average annual rainfall is varies from 1100 to $1500 \mathrm{~mm}$. The humidity is high in monsoon season, from $75 \%$ to $85 \%$. But in hot summer it goes down from $35 \%$ to $25 \%$. Temperature 
varies over a wide range from $77^{\circ} \mathrm{C}$ in winter to $46.8^{\circ} \mathrm{C}$ in the summer. Due to undulated topography just about fifty percent of the total rainfall flows away as run off (5). The total goat population of Purulia is 813191 (7).

2.2.2. Nadia, fall under Lower Gangetic Plains region of India (6). About $68 \%$ of the land is cultivated. The soil of this sub-zone is deltaic alluvial and the climate is per humid to humid. Annual rainfall ranging between $1,200 \mathrm{~mm}$ and $1,700 \mathrm{~mm}$. The zone has a tropical climate with a short spell of winter season. The hot season lasts from mid-March to mid-June, with the day temperature ranging from $38^{\circ} \mathrm{C}$ to $45^{\circ} \mathrm{C}$ in different parts of this region. The monsoon arrives by the month of middle June. Winter extends about three months; the average minimum temperature not goes down below $10^{\circ} \mathrm{C}$. Average rainfall of this area is $1,435.8 \mathrm{~mm}$ (6). The total goat population of Nadia is 952143 (7).

2.3. Climatological measurement: The three year data on temperature of the study area has been collected from the state meteorological department and the mean of the three years with standard deviation was calculated (Table 1) using MS-Excel 2007 and shown here in a tabular form (Table 1).

Table 1. Mean maximum and minimum temperature of last three years

\begin{tabular}{llllll} 
& & \multicolumn{4}{l}{ Nadia } \\
\cline { 3 - 5 } Seasons & Months & Max $\left({ }^{\circ} \mathrm{C}\right)$ & $\operatorname{Min}\left({ }^{\circ} \mathrm{C}\right)$ & $\operatorname{Max}\left({ }^{\circ} \mathrm{C}\right)$ & Min $\left({ }^{\circ} \mathrm{C}\right)$ \\
\hline Pre-Monsoon & March & $40.4 \pm 2.3$ & $21.6 \pm 10.9$ & $37 \pm 2.45$ & $16 \pm 3.9$ \\
& April & $42.6 \pm 1.5$ & $21 \pm 0.7$ & $38 \pm 1$ & $19.4 \pm 3.3$ \\
& May & $42.6 \pm 1.5$ & $22.4 \pm 1.1$ & $39.2 \pm 1.5$ & $23.4 \pm 1.5$ \\
& June & $38.6 \pm 5.0$ & $23.2 \pm 0.8$ & $36 \pm 4.7$ & $23.6 \pm 1.3$ \\
\hline Post-Monsoon & November & $32.0 \pm 1.0$ & $13.6 \pm 1.1$ & $31.6 \pm 1.2$ & $14.4 \pm 2.8$ \\
& December & $30.8 \pm 2.2$ & $9.4 \pm 1.7$ & $28.75 \pm 0.5$ & $11.5 \pm 1.3$ \\
& January & $30.0 \pm 2.5$ & $8.6 \pm 0.9$ & $28.6 \pm 1.5$ & $10.2 \pm 1.6$ \\
& February & $34.6 \pm 2.5$ & $11 \pm 2.5$ & $32.2 \pm 3.6$ & $12.6 \pm 3$ \\
\hline
\end{tabular}

2.4. Blood collection and clinical analysis: Data on blood parameters have been collected on apparently healthy goats using purposive sampling technique (8) for the year and categorized into two seasons. The seasons include pre-monsoon and post-monsoon. About $4 \mathrm{ml}$ of blood was collected by jugular venipuncture from each goat between 12 o'clock to $2 \mathrm{pm}$ under the intense sun using disposable Vacutainer needles and tubes (9). The collected blood has been dispensed into di-potassium ethylene di-amine tetra acetic acid $\left(\mathrm{K}_{2}\right.$ EDTA $)$ vials and labeled accordingly. The anticoagulants mixed blood then used to analyze for the packed cell volume (PCV), erythrocyte or red blood cell (RBC), haemoglobin (Hb). Total erythrocyte count (TEC) or the RBC count (calculated in $10^{6} / \mu \mathrm{l}$ ) has been done with the help of improved Neubauer counting chamber $(10,11)$. The total hemoglobin (calculated in $\mathrm{g} / \mathrm{dl}$ ) concentration in blood has been determined by the Drabkins method (cyanmethaemoglobin method) (12). Determination of Hematocrit value or PCV (in \%) has been done by hematocrit tube method andmean corpuscular volume ormean cell volume or MCV (infemtoliter per cell or $\mathrm{fl}$ ), mean corpuscular hemoglobin or $\mathrm{MCH}$ (in picogram per cell or pg) and mean corpuscular hemoglobin concentration or MCHC (in \%) have been calculated from the values of PCV, RBC and $\mathrm{Hb}(10)$. Blood $\mathrm{pH}$ has been studied on field using $\mathrm{pH}$ meter. Blood glucose level $(\mathrm{mg} / \mathrm{dl})$ has been analyzed by glucose oxidase method as modified by Gochman and Schmitz (13).

2.5. Statistical analysis: The statistical analysis of the data was performed using SPSS 21.01 (14). Analysis of variance (ANOVA) test was used to determine the effects of season and the two different agro climatic regions studied here on the parameters (15). Mean separation has been performed using MS-Excel 2007.

\section{Results:}

The result obtained from the present study reveals that in Nadia, blood $\mathrm{pH}(\mathrm{p}<0.05)$ and blood glucose level $(p<0.01)$ in black Bengal goats are significantly increase during post-monsoon. When compared to the post-monsoon hemoglobin level significantly $(\mathrm{p}<0.01)$ increase in pre-monsoon. During post-monsoon RBC count non- significantly increase than in pre-monsoon. PCV, MCV and $\mathrm{MCH}$ values also show significant $(\mathrm{p}<0.01)$ increase in pre-monsoon. MCHC shows no significant difference between the two seasons (Table 2).

Table 2. Effect of the seasonal variation on the bio-chemicals parameters in Nadia

\begin{tabular}{|c|c|c|c|c|}
\hline Parameters (Units) & Pre-monsoon & Post-monsoon & Overall & $P$ value \\
\hline Blood pH & $7.31 \pm 0.06$ & $7.63 \pm 0.07$ & $7.47 \pm 0.31$ & $0.018^{*}$ \\
\hline Glucose (mg/dl) & $43.6 \pm 6.27$ & $59.25 \pm 2.66$ & $51.42 \pm 9.3$ & $0.00000027^{* *}$ \\
\hline $\mathrm{Hb}(\mathrm{g} / \mathrm{dl})$ & $12.7 \pm 0.63$ & $8.45 \pm 1.5$ & $10.58 \pm 2.45$ & $0.000000045^{* *}$ \\
\hline $\mathrm{RBC}$ (millions $/ \mathrm{mm}^{3}$ ) & $7.15 \pm 0.98$ & $9.188 \pm 2.79$ & $8.17 \pm 2.28$ & $0.14^{\mathrm{NS}}$ \\
\hline $\operatorname{PCV}(\%)$ & $37.05 \pm 1.86$ & $26.07 \pm 4.02$ & $31.56 \pm 6.4$ & $0.00000017^{* *}$ \\
\hline $\operatorname{MCV}(\mathrm{fl})$ & $52.48 \pm 6.02$ & $29.9 \pm 6.78$ & $41.23 \pm 13.11$ & $0.00000069^{* *}$ \\
\hline $\mathrm{MCH}$ (pg/ cell) & $18 \pm 2.02$ & $9.87 \pm 2.16$ & $13.84 \pm 4.73$ & $0.00000012^{* *}$ \\
\hline $\mathrm{MCHC}(\%)$ & $33.91 \pm 0.61$ & $33.26 \pm 0.82$ & $33.59 \pm 0.78$ & $0.061^{\mathrm{NS}}$ \\
\hline
\end{tabular}


In Purulia, blood $\mathrm{pH}$ significantly $(\mathrm{p}<0.01)$ lowers whereas $\mathrm{Hb}$ level significantly increases with concomitant decrease of TEC in pre-monsoon season.. PCV, MCV and MCH value also show significant $(\mathrm{p}<0.01)$ increase in pre-monsoon similar to the trend found in Nadia (shown in Table 2). In Purulia blood glucose level and MCHC value shows no significant difference between the two seasons (Table 3).

Table 3. Effect of the seasonal variation on the bio-chemicals parameters in Purulia

\begin{tabular}{|c|c|c|c|c|}
\hline Parameters (Units) & Pre-monsoon & Post-monsoon & Overall & $\mathrm{P}$ value \\
\hline Blood $\mathrm{pH}$ & $7.32 \pm 0.24$ & $7.74 \pm 0.12$ & $7.48 \pm 0.29$ & $0.0002^{* *}$ \\
\hline Glucose $(\mathrm{mg} / \mathrm{dl})$ & $45.1 \pm 5.75$ & $48.23 \pm 5.87$ & $47.05 \pm 5.88$ & $0.25^{\mathrm{NS}}$ \\
\hline $\mathrm{Hb}(\mathrm{g} / \mathrm{dl})$ & $9.76 \pm 0.5$ & $8.54 \pm 0.7$ & $9.15 \pm 0.9$ & $0.0004^{* *}$ \\
\hline $\mathrm{RBC}$ (millions $/ \mathrm{mm}^{3}$ ) & $7.5 \pm 1.5$ & $9.59 \pm 1.4$ & $8.5 \pm 1.8$ & $0.005^{* *}$ \\
\hline $\operatorname{PCV}(\%)$ & $28.65 \pm 1.8$ & $25.61 \pm 2.1$ & $27.31 \pm 2.5$ & $0.0008^{* *}$ \\
\hline $\operatorname{MCV}(\mathrm{fl})$ & $39.55 \pm 7.9$ & $27.28 \pm 4.7$ & $33.63 \pm 8.9$ & $0.003^{* *}$ \\
\hline $\mathrm{MCH}(\mathrm{pg} /$ cell $)$ & $13.45 \pm 2.6$ & $9.1 \pm 1.6$ & $11.28 \pm 3.1$ & $0.003^{* *}$ \\
\hline $\mathrm{MCHC}(\%)$ & $34.08 \pm 0.8$ & $33.35 \pm 0.8$ & $33.52 \pm 0.8$ & $0.34^{\mathrm{NS}}$ \\
\hline
\end{tabular}

During the seasonal analysis, the blood $\mathrm{pH}$ value shows no significant difference between Purulia and Nadia in the season of pre-monsoon. Blood glucose as well as Hb level increase significantly $(p<0.01)$ in Nadia where as RBC values shows no significant difference between the two regions in the season of pre-monsoon. $\mathrm{PCV}, \mathrm{MCV}$ and $\mathrm{MCH}$ values significantly increase $(\mathrm{p}<0.01)$ in Nadia during pre-monsoon. MCHC shows no significant difference between the two regions (Table 4$)$.

Table 4. Effect of the regional variation on the bio-chemicals parameters in pre-monsoon

\begin{tabular}{|c|c|c|c|c|}
\hline Parameters (Units) & Purulia & Nadia & Over all & $\mathrm{P}$ value \\
\hline Blood $\mathrm{pH}$ & $7.32 \pm 0.24$ & $7.25 \pm 0.25$ & $7.31 \pm 0.24$ & $0.76^{\mathrm{NS}}$ \\
\hline Glucose $(\mathrm{mg} / \mathrm{dl})$ & $48.23 \pm 5.87$ & $59.12 \pm 3.43$ & $51.67 \pm 7.3$ & $0.00062^{* *}$ \\
\hline $\mathrm{Hb}(\mathrm{g} / \mathrm{dl})$ & $9.76 \pm 0.5$ & $12.7 \pm 0.63$ & $11.24 \pm 1.6$ & $0.0000000018^{* *}$ \\
\hline $\mathrm{RBC}$ (millions $/ \mathrm{mm}^{3}$ ) & $7.5 \pm 1.5$ & $7.15 \pm 0.98$ & $7.33 \pm 1.2$ & $0.549^{\mathrm{NS}}$ \\
\hline $\operatorname{PCV}(\%)$ & $28.65 \pm 1.8$ & $37.05 \pm 1.86$ & $33.03 \pm 4.48$ & $0.0000000091^{* *}$ \\
\hline $\operatorname{MCV}(\mathrm{fl})$ & $39.55 \pm 7.9$ & $52.48 \pm 6.02$ & $46.23 \pm 9.28$ & $0.00074^{* *}$ \\
\hline $\mathrm{MCH}(\mathrm{pg} /$ cell $)$ & $13.45 \pm 2.6$ & $18 \pm 2.02$ & $15.74 \pm 3.25$ & $0.00038^{* *}$ \\
\hline $\mathrm{MCHC}(\%)$ & $34.08 \pm 0.8$ & $34.31 \pm 0.65$ & $34 \pm 0.76$ & $0.06^{\mathrm{NS}}$ \\
\hline
\end{tabular}

During the season of post-monsoon, blood $\mathrm{pH}$ value only shows significant increase $(\mathrm{p}<0.01)$ in Nadia than Purulia. All other values such are blood glucose; Hb, PCV, MCV and MCH show no significant difference between two regions. MCHC also shows no significant difference between the two regions. The non significant values suggest here that there are little physio-biochemical changes among the animals during the season of post-monsoon in between those two regions (Table 5).

Table 5. Effect of the regional variation on the bio-chemicals parameters in post-monsoon

\begin{tabular}{lllll}
\hline Parameters (Units) & Purulia & Nadia & Over all & P value \\
\hline Blood pH & $7.7375 \pm 0.12$ & $8.206 \pm 0.22$ & $7.99 \pm 0.3$ & $0.00007^{* *}$ \\
Glucose $(\mathrm{mg} / \mathrm{dl})$ & $43.58375 \pm 7.1$ & $45.137625 \pm 5.7$ & $44.4 \pm 6.3$ & $0.63^{\mathrm{NS}}$ \\
$\mathrm{Hb}(\mathrm{g} / \mathrm{dl})$ & $8.54 \pm 0.7$ & $8.45 \pm 1.5$ & $8.5 \pm 1.1$ & $0.864^{\mathrm{NS}}$ \\
$\mathrm{RBC}\left(\mathrm{millions} / \mathrm{mm}^{3}\right)$ & $9.59 \pm 1.4$ & $9.188 \pm 2.79$ & $9.39 \pm 2.16$ & $0.689^{\mathrm{NS}}$ \\
$\mathrm{PCV}(\%)$ & $25.61 \pm 2.1$ & $26.07 \pm 4.02$ & $25.8 \pm 3.1$ & $0.748^{\mathrm{NS}}$ \\
$\mathrm{MCV}(\mathrm{fl})$ & $27.28 \pm 4.7$ & $29.9 \pm 6.78$ & $28.63 \pm 5.85$ & $0.31^{\mathrm{NS}}$ \\
$\mathrm{MCH}(\mathrm{pg} /$ cell) & $9.1 \pm 1.6$ & $9.87 \pm 2.16$ & $9.39 \pm 1.87$ & $0.5^{\mathrm{NS}}$ \\
$\mathrm{MCHC}(\%)$ & $33.35 \pm 0.8$ & $32.35 \pm 2$ & $32.85 \pm 1.57$ & $0.159^{\mathrm{NS}}$ \\
\hline \multicolumn{5}{l}{}
\end{tabular}

Here we also calculate all the parameters in season wise to evaluate show the physiological changes according to seasonal variation. The blood $\mathrm{pH}$ count has been significantly higher $(\mathrm{p}<0.01)$ in post-monsoon. There are no significant differences in blood glucose value as well as RBC value between two seasons. Hb level shows significant increase in pre-monsoon than post-monsoon. PCV, MCV as well as MCH values show significant $(\mathrm{p}<0.01)$ decrease in post-monsoon. MCHC also shows no significant difference between the two seasons (Table 6).

There are significant higher $(\mathrm{p}<0.05) \mathrm{pH}$ value in Purulia than Nadia when compared among the region. Blood glucose value shows no significant difference between two regions. PCV value has been 
significantly $(\mathrm{p}<0.01)$ higher in Nadia whereas MCV and MCH significantly lower $(\mathrm{p}<0.05)$ in Purulia. MCHC also shows no significant difference between the two regions studied here (Table 7).

Table 6. Effect of the seasonal variation on the bio-chemicals parameters on all the animals

\begin{tabular}{|c|c|c|c|c|}
\hline Parameters (Units) & Pre-monsoon & Post-monsoon & Over all & $\mathrm{P}$ value \\
\hline Blood $\mathrm{pH}$ & $7.31 \pm 0.24$ & $7.99 \pm 0.3$ & $7.6 \pm 0.44$ & $0.00005^{* *}$ \\
\hline Glucose (mg/dl) & $44.4 \pm 6.3$ & $51.67 \pm 7.3$ & $48.33 \pm 7.7$ & $0.078^{\mathrm{NS}}$ \\
\hline $\mathrm{Hb}(\mathrm{g} / \mathrm{dl})$ & $11.24 \pm 1.6$ & $8.5 \pm 1.1$ & $9.87 \pm 1.96$ & $0.0053^{* *}$ \\
\hline $\mathrm{RBC}$ (millions $/ \mathrm{mm}^{3}$ ) & $7.33 \pm 1.2$ & $9.39 \pm 2.16$ & $8.36 \pm 2.04$ & $0.075^{\mathrm{NS}}$ \\
\hline PCV $(\%)$ & $33.03 \pm 4.48$ & $25.8 \pm 3.1$ & $29.44 \pm 5.27$ & $0.0068^{* *}$ \\
\hline $\operatorname{MCV}(\mathrm{fl})$ & $46.23 \pm 9.28$ & $28.63 \pm 5.85$ & $37.43 \pm 11.75$ & $0.0026^{* *}$ \\
\hline $\mathrm{MCH}$ (pg/cell) & $15.74 \pm 3.25$ & $9.39 \pm 1.87$ & $12.56 \pm 4.14$ & $0.0019^{* *}$ \\
\hline $\mathrm{MCHC}(\%)$ & $34 \pm 0.76$ & $32.85 \pm 1.57$ & $33.42 \pm 1.34$ & $0.15^{\mathrm{NS}}$ \\
\hline
\end{tabular}

Table 7. Effect of the regional variation on the bio-chemicals parameters on all the animals

\begin{tabular}{|c|c|c|c|c|}
\hline Parameters (Units) & Purulia & Nadia & Over all & P value \\
\hline Blood pH & $7.48 \pm 0.29$ & $7.47 \pm 0.31$ & $7.6 \pm 0.44$ & $0.048^{*}$ \\
\hline Glucose (mg/dl) & $47.05 \pm 5.88$ & $51.42 \pm 9.3$ & $48.3 \pm 7.7$ & $0.24^{\mathrm{NS}}$ \\
\hline $\mathrm{Hb}(\mathrm{g} / \mathrm{dl})$ & $9.15 \pm 0.9$ & $10.58 \pm 2.45$ & $9.9 \pm 1.96$ & $0.019^{*}$ \\
\hline $\mathrm{RBC}$ (millions $/ \mathrm{mm}^{3}$ ) & $8.5 \pm 1.8$ & $8.17 \pm 2.28$ & $8.4 \pm 2.04$ & $0.57^{\mathrm{NS}}$ \\
\hline $\mathrm{PCV}(\%)$ & $27.31 \pm 2.5$ & $31.56 \pm 6.4$ & $29.4 \pm 5.3$ & $0.008^{* *}$ \\
\hline $\operatorname{MCV}(f l)$ & $33.63 \pm 8.9$ & $41.23 \pm 13.11$ & $37.4 \pm 11.75$ & $0.039^{*}$ \\
\hline $\mathrm{MCH}$ (pg/ cell) & $11.28 \pm 3.1$ & $13.84 \pm 4.73$ & $12.6 \pm 4.14$ & $0.049^{*}$ \\
\hline $\mathrm{MCHC}(\%)$ & $33.52 \pm 0.8$ & $33.33 \pm 1.76$ & $33.4 \pm 1.34$ & $0.671^{\mathrm{NS}}$ \\
\hline
\end{tabular}

\section{Discussion}

During the experimental period, the animals (here black Bengal goat) have been exposed to marked seasonal changes in ambient temperature. Seasonal changes influence the physiological responses of the animals in dissimilar way. It is known that each and every individual biological organism is somehow different from other individuals of same group. So, their responses to same environment can be different from others. The goat body temperature rises along with the elevated ambient temperature, which secondarily increase the water uptake by the goat $(16,17)$. Under subtropical conditions, the water consumption of goats has been much higher during pre-monsoon than in post-monsoon (18). The enormous drinking of water reduces the feed intake in extreme heat condition in pre-monsoon (19). These nutritional modifications are manipulating the composition of blood in goats (20).

Blood $\mathrm{pH}$ values in pre-monsoon are lower than post-monsoon in both the region i.e. Purulia and Nadia (Table 2, 3, 5 and 6). It shows that during season of high ambient temperature arterial blood becomes more or less acidic, which may be an outcome of nutritional modification happens at that time. Goats from Purulia always show lower $\mathrm{pH}$ values in blood (Table 4 and 7), which may be an effect of regional variations. Blood $\mathrm{pH}$ also a has relation with thedifferent bio-physical parameters likearterial blood pressure, blood gases, rectal temperature, heart and respiratory rates (21) and variation among them also cause variation in blood $\mathrm{pH}$ values (21). The blood glucose level always has been higher in post-monsoon. This is most likely due to the fact that during pre-monsoon season glucose consumption has been high in the body since there was less forage to intake. To afford more energy to the animal in order to disperse more heat to maintain the body temperature at normal level, and in the season of pre-monsoon, the feed intake is depressed due to high ambient temperature which confirms with the findings of other workers (22). This may be the same reason for having lower blood glucose level in Purulia than Nadia.

Decline in erythrocyte or RBC count in Purulia and Nadia during the season of pre-monsoon may be related to decrease of thyroid hormones secretion which is related to declining the process of erythropoiesis (23). The higher mean values of erythrocyte count in Purulia and Nadia (Table 5) during post-monsoon in the present study may be associated with improvement of nutritional status of goats, which is supported by other workers in sheep $(24,25)$. The present results for seasonal changes in erythrocyte count are similar as the other workers. Who had been (26) reported higher values of PCV and Hb during pre-monsoon compared to the postmonsoon but some other workers (27) found that decline in erythrocyte count along with sharp decline in PCV and $\mathrm{Hb}$ count in the season of pre-monsoon. Cameroon goats kept in temperate environment (28) shows lower values of $\mathrm{Hb}, \mathrm{PCV}$ and $\mathrm{RBC}$ total count in post-monsoon. These variations of responses of goats may be attributed to divergence in ambient temperature as well as the variation in agro-climatic regions.

The current results indicate that MCV and $\mathrm{MCH}$ values have been significantly low in post-monsoon (Table 2, 3 and 6) in both Purulia and Nadia. It is also observed that throughout the year MCV and MCH values are comparatively higher in Nadia (Table 4, 5 and 7). The lowest mean MCV value (27.28 fl) has been obtained in the season of post-monsoon in Purulia with the highest number of mean erythrocyte counts (9.59 millions $/ \mathrm{mm}^{3}$ ). The low MCV value obtained could be connected to the negative correlation among size and 
number of erythrocytes (29). MCV and MCH values obtained in the present study during post-monsoon are in general accordance with the findings of other workers (30), who reported higher MCV and MCH values in postmonsoon condition.

MCHC values remain unchanged throughout the year as well as in two different agro-climatic regions. The constant values of MCHC in the current study may be documented to associated increase or decrease in $\mathrm{Hb}$ concentration or PCV levels. As many workers (19) reported more or less steady level of MCHC during different seasons.

Due to wide range of undulated topography in Purulia about fifty percent of the total rainfall flows away as run off (4) so through the year there are less forage to graze and in the season of pre-monsoon the condition of animals become severe due to least forage availability and scarcity of water. These may be the cause behind the significant variation of biochemical parameters of goats between the two seasons before and after monsoon in Purulia and in between the regions Purulia and Nadia. On the other hand the animals in Nadia get chance to graze throughout the year with less water scarcity. The variation of biochemical responses of goats, in Nadia occurs only due to the seasonal variation. So, now we can conclude that the seasonal changes or the changes in ambient temperature may not only the factor that influences the physio-biochemical response of goats there are some effects of regional variations are also present.

\section{References}

[1]. Biswas S. The Black Bengal Goat as a Tool to Promote Sustainable Livelihoods in Rural West Bengal. In: Pinstrup-Andersen P, Cheng F, editors. Food Policy for Developing Countries. Case Studies 7-10. Ithaca, New York: Cornell University; 2010. pp 1-12

[2]. Arnaudov A. Serologicalsurvey for BrucellaovisDissemination among goats(Capra aegagrushircus) J Centr Euro Agri. 2012; 13(1): $188-192$

[3]. Silanikove N. The physiological basis of adaptation in goats to harsh environments. Small Ruminant Res. 2000; 35: 181-193

[4]. Celi P.The role of oxidative stress in small ruminants' health and production. R. Bras. Zootec. 2010; 39, suppl.: 348-363

[5]. Pandey MM. Long-term Strategies and Programmes for Mechanization of Agriculture in Agro Climatic Zone-VII: Eastern Plateau and Hills region, Department of Agriculture \& Co-operation, Ministry of Agriculture. Govt. India. 2006; pp. 144 - 168.

[6]. Sirohi NPS. Long-term Strategies and Programmes for Mechanization of Agriculture in Agro Climatic Zone-III: Lower Gangetic Plains region, Department of Agriculture \& Co-operation, Ministry of Agriculture. Govt. India. 2006; pp. 96 - 105

[7]. Livestock Population West Bengal Hand book, 2009

[8]. Tongco MDC. Purposive Sampling as a Tool for Informant Selection, EthnobotanyRes Appli. 2007; 5:147-158

[9]. Coles EM. Vetenary Clinical Pathology. 3 rd Ed., WB Saunders, Philadelphia; 1980

[10]. Jain NC. Haematologic techniques. In: Schalm's Veterinary Haematology. Philadelphia: Lea and Febiger; 1986.

[11]. Dacie JV, Lewis SM. Practical Haematology. Edinburgh: Churchill Livingstone, 1990.

[12]. Balasubramaniam P, Malathi, A. Comparative study of hemoglobin estimated by Drabkin's and Sahli's methods. J. Postgrad. Med., 1992; 38: 8-9.

[13]. Gochman N, Schmitz JM. Applications of new peroxide indicator reaction to the specific, automated determination of glucose with glucose oxidase. ClinChem. 1972; 18: 943-949

[14]. IBM SPSS Statistics 21 Core System User's Guide. IBM. 2012; pp 337-343

[15]. McDonald JH. Hand Book of Biological Statistics. Baltimore, Maryland: Sparky House Publishing; 2008.

[16]. Maloiy GMO, Taylor CR. Water requirements of African goats and haired sheep. J. Agri Sci. Cambridge. 1971; 77: $203-208$.

[17]. Quartermain AR, Broadbent MP. Some patterns of response to climate by Zambian goats. East African Agri and Forestry J. 1974; 40: $115-124$

[18]. Hadjipanayiotou M. Fractional outflow of soybean meal from the rumen, water intake and ruminal fermentation pattern in sheep and goats at different seasons and age groups. Small Ruminant Res. 1995; 17: 137-143.

[19]. Bhatta M, Das D, Ghosh PR. Seasonal Variation in Erythrocytic Indices of Black Bengal Goats (Capra aegagrushircus) in Purulia, West Bengal, Ind J Anim Health. 2013; 52(1): 43-48

[20]. Olafadehan O A. Changes in haematologicaland biochemical diagnostic parameters of red Sokoto goats fed tannin-rich Pterocarpuserinaceusforage diets. Vet. Arhiv. 2011 81, 471-483

[21]. Afshar FS, Baniadam A, Marashipour SP, Effect of xylazine-ketamine on arterial blood pressure, arterial blood ph, blood gases, rectal temperature, heart and respiratory rates in goats. Bull Vet InstPulawy. 2005; 49: 481-484.

[22]. Sandabe UK, Chaudhary SUR. Effect of environmental temperature on some biochemical values in female sahel goats. Pak Vet. J. 2000; 20 (1) 10-12.

[23]. Dainiak N, Hoffman R, Maffei LA, Forget BG. Potentiation of human erythropoiesis in vitro by thyroid hormone. Nature. 1978; 272: $260-262$.

[24]. Macfarlane WV, Howard B, Morris RJH. Water metabolism of Merino sheep shorn during summer. Aus J AgriRes. 1966; 17: 219 225.

[25]. Kaushish S, Bhattia DC, Arora KL. Studies on the adaptability of sheep to subtopical climate and seasonal changes in rectal temperature, cardiorespiratory and haematological attributes of Nali sheep. Ind Vet J. 1976; 33: 760-765.

[26]. Holman HH, Dew SM. The blood picture of the goat. V-variations due to season, sex and reproduction. Res Vet Sci. 1966; 7: $276-$ 286.

[27]. Mehrotra PN, Mullick DN, Kehar ND. Seasonal variation in the blood composition of sheep. J Anim Sci. 1954; 13: 1026

[28]. Pospisil J, Kase F, Vahala J. Basic haematological values in the Cameroon goat (Capra hircus). Comp Biochem Physiol. 1987; 88A: 451-545.

[29]. Holman HH, Dew SM. The blood picture of the goat. II. Changes in erythrocytc shape, size and number associated with age. Res. Vet Sci. 1964; 5: 274-285.

[30]. Gutierrez-De La R JH, Warnick AC, Cowley JJ, Hentgs JF. Environmental physiology in the substropics. I. Effect of stress in some haematological values of beef cattle. J Anim Sci. 1971; 32: 968-973. 